\title{
Correlation between total lymphocyte counts and CD4 among human immunodeficiency virus (HIV) patients
}

\author{
I M S Darmana ${ }^{1}, N W$ Rusni $^{2}$, and $S$ Masyeni $^{2, *}$ \\ ${ }^{1}$ Universitas Warmadewa Denpasar Bali, Sanjiwani Hospital/Faculty of Medicine and Health Sciences, Indonesia \\ ${ }^{2}$ Universitas Warmadewa Denpasar Bali, Faculty of Medicine and Health Sciences, Indonesia
}

\begin{abstract}
Although the CD4+ T-lymphocyte is considered the best HIV disease progression marker, in underdevelopment countries the measurement of CD4 is remaining a problem due to high expense and less availability of the tool. In contrast with the total lymphocyte count (TLC) that is widely available and less expensive is another way to assess the HIV disease progression. This study was an observational study to identify the correlation between CD4 cell count and TLC in HIV infected patient at Sanjiwani Hospital Bali during May through June 2016. A total of 33 serum sample was enrolled in the study. The TLC number was around $300-10.300$ cells $/ \mu \mathrm{L}$ and the mean TLC was $2.018,18$ cells $/ \mu \mathrm{L}$ (SD 1.871,91 cells $/ \mu \mathrm{L}$ ) Result showed that there is correlation between TLC and CD4 $(r=0.811 ; \mathrm{p}=0.000)$. In conclusion, the TLC can therefore adequately serve as a surrogate marker for CD4 in HIV infected patient in order to ART initiation or to assess disease progression.
\end{abstract}

\section{Introduction}

Progressive decreasing of CD4+ T-lymphocyte population is a hallmark of Human Immunodeficiency Virus-1 (HIV-1) due to the destruction of this cell by the virus [1]. Disease progression in HIV-1 infection may take several years in the common population. However, the rapid progression has been reported in a minority of the patient [2,3]. In the evaluation of the patients infected with HIV infection, the CD4 count is the best important laboratory indicator of immune function. Studies show, CD4 count is also the strongest predictor of disease progression [4,5]. Determining of the CD4 count at the first entry is mandatory due to the ability of the CD4 count reflects the immune status in order to initiate the ART. [6] In addition, CD4 count is also used to initiate Opportunistic Infection (OI) prophylaxis, ART response monitoring or assessing immunological failure or therapeutic response monitoring [7-9]. The total CD4 count is a calculated value based on the total white blood cell (WBC) count and the percentages of total and CD4+ $\mathrm{T}$ lymphocytes. The superiority of the CD4 is well established in HIV infection but sometimes CD4 count is a failure to reflect the real immune status in HIV infection. There are several condition influences the fluctuating number of CD4 in individuals and may be influenced by factors that may affect the total WBC count and lymphocyte percentages, such as the use of the suppressive effect of medications to the bone marrow or the presence of acute infections. In HIV infection, spleenectomy, corticosteroid, sepsis, malaria, tuberculosis, and co-infection with human $\mathrm{T}$ lymphotropic virus type I (HTLV-1) may cause misleadingly raised CD4 counts. Interleukin-2, alphainterferon may decrease the absolute CD4 count without changing the CD4 percentage [10-14]. Based on those studies, the CD4 percentage remains constant and maybe a more proper parameter to assess a patient's immune function.

In developed countries, the using of viral load and the CD4 count has been well-adopted. In contrast with underdevelopment countries, the high cost of both tools is a barrier in the management of HIV infection. The CD4 count is not readily available throughout the year. According to this fact WHO stipulates that CD4 count is suitable but not essential to initiate ART in developing countries or remote area [15]. Then WHO commended the use of total lymphocyte count (TLC) as an alternative marker of CD4 count: a total lymphocyte count of fewer than 1,000-1,200 lymphocytes/mm3may be used as a threshold value to initiate HIV therapy [16]. Most studies conducted to a relationship between TLC and CD4 count in HIV infected patients $[15,17,18]$. Total lymphocyte count is readily available, inexpensive and a simple tool to reflect the immune status of the patients. The aim of this study is to review the correlation between TLC and CD4 count in a patient with HIV infection.

\section{Material and methods}

This study was conducted with approval from the Medical Research Ethics Committees of Sanjiwani Hospital. All study participants were enrolled after providing written informed consents. Samples were collected consecutively. Thirty-three HIV-infected

\footnotetext{
* Corresponding author: masyeniputu@yahoo.com
} 
individuals were recruited from Sinta HIV Clinic of Sanjiwani Hospital at Gianyar regency. Three milliliters of whole blood samples were collected using ethylenediamine-tetra-acetic acid (EDTA) from study participants during March to June 2016. Demographic, clinical and haematological data, as well as disease severity according to the WHO guidelines of study participants, were retrieved from the medical record. TLC was determined using Mindray-BC 3600 which is principally detecting electrical voltage as result of blood suspension through the device. The CD4 count was assayed with PIMA device according to the manufacturer's instruction.

The continuous variables were presented as mean and standard deviation using independent student t-test. Pearson correlation was performed to see the correlation between TLC and CD4 count. The level of significance was defined at $95 \%$ confidence interval and a $\mathrm{P}$ value less than 0.05 were considered significant. The statistical analyses were performed using SPSS software (version 16).

\section{Results and discussion}

Phytochemical The HIV diagnosis was confirmed with Rapid test according to the Indonesian Guideline in assessing HIV infection [8]. We analysed the patients' demographics and in term of gender, we observed the unequal proportion between male and female. Among the 33 participants, this comprises $20(60.6 \%)$ male and $13(39.4 \%)$ female. Risk factors to get the HIV infection were found in all of the participants (Table 1) in which unsafe sex was found as the most $(72.7 \%)$ risk factor in this study. Homosexual was found as high as $9.1 \%$. Interestingly, mother-to-child HIV transmission or perinatal transmission was also found $(9.1 \%)$ in this study.

Table 1. Characteristics of the participants.

\begin{tabular}{|c|c|}
\hline Variable & $(\mathrm{N}=33)$ \\
\hline \multicolumn{2}{|l|}{ Age (year) } \\
\hline$-\quad$ Mean \pm SD & $33.75 \pm 14.54$ \\
\hline$-\quad \mathrm{IQR}$ & $1-64$ \\
\hline \multicolumn{2}{|l|}{ Seksual orientation: } \\
\hline - $\quad$ Heteroseksual (\%) & $27(81.8)$ \\
\hline - $\quad$ Homoseksual (\%) & $3(9.1)$ \\
\hline - $\quad$ Unknown $(\%)$ & $3(9.1)$ \\
\hline \multicolumn{2}{|l|}{ Occupation: } \\
\hline$-\quad$ Yes $(\%)$ & $22(66.7)$ \\
\hline - Unemployment $(\%)$ & $11(33.3)$ \\
\hline \multicolumn{2}{|l|}{ Risk Factors : } \\
\hline - Unsafe-sex (\%) & $24(72.7)$ \\
\hline$-\quad$ Wife $(\%)$ & $3(9.1)$ \\
\hline - $\quad$ Homoseksual (\%) & $3(9.1)$ \\
\hline$-\quad$ Perinatal $(\%)$ & $3(9.1)$ \\
\hline \multicolumn{2}{|l|}{$\begin{array}{l}\text { Total lymphocyte count } \\
\text { (celsl/ } \mu \mathrm{L})\end{array}$} \\
\hline $\begin{array}{ll}- & \text { Mean } \pm S D \\
- & \text { IQR }\end{array}$ & $\begin{array}{c}2018.18 \pm 1871.91 \\
300-10300\end{array}$ \\
\hline \multicolumn{2}{|l|}{ Limfosit T-CD4 $^{+}($cells $/ \mu \mathrm{L})$} \\
\hline$-\quad$ Mean \pm SD & $268.36 \pm 336.78$ \\
\hline$-\quad \mathrm{IQR}$ & $7-1351$ \\
\hline
\end{tabular}

A majority (81.8\%) of the participants have a heterosexual orientation. Gianyar regency is one of the most visited tourist destinations in Bali. Based on the participant's address, $21.2 \%$ of them live around Gianyar city, $15.2 \%$ in Ubud and also Payangan village, $9.1 \%$ in Blahbatuh and Tegalalang and $6.1 \%$ from Tampaksiring village. The main age group of the participants was age group 20-39 years $(66.67 \%)$.

The table shows the total lymphocyte count of the participants was between $300-10300$ cells $/ \mu \mathrm{L}$ (2018.18 \pm 1871.91$)$. Meanwhile, the mean CD4 count was 268.36 \pm 336.78 (CD4 count range between 7-1 351) cells/ $\mu \mathrm{L}$. Majority $(18 / 54.5 \%)$ of the participants has CD4 count less than 200 cells $/ \mu \mathrm{L}$, followed by CD4 count $200-499$ cell $/ \mu \mathrm{L}$ and $\geq 500$ cells $/ \mu \mathrm{L}$, account for $33.3 \%, 12.1 \%$, respectively. Participants with a CD4 count less than 350 cell $/ \mu \mathrm{L}$ found as high as $75.8 \%$. This result indicates almost three-fourths of the participants needs to initiate the antiretroviral therapy. Correlation between TLC and CD4 count was analyzed with Pearson test. The result (Figure) revealed a positive correlation between the two variables, in which $\mathrm{r}=0,811 \mathrm{p}=$ 0,000 ). According to the ROC curve, a threshold value of TLC as high as 1450 cells $/ \mu \mathrm{L}$ is compatible with CD4 count $<200$ cells $/ \mu \mathrm{L}$, sensitivity $80 \%$ but low specificity of only $67 \%$ (AUC 0.844 ). A better sensitivity $(87.5 \%$ ) and specificity $(80 \%)$ found when we used a threshold value of TLC 1650 cell $/ \mu \mathrm{L}$ for CD 4 count $<350$ cell $/ \mu \mathrm{L}$.

It is not surprising, the entire world has been grappling with the rapid spread of HIV/AIDS with an estimation that more than $90 \%$ of the HIV patients living in developing countries or low- to middle-income countries [19]. With the introducing of ART for the treatment, HIV infection has been noticeably found as a chronically manageable disease [20] with a further problem related to ART toxicity, HIV itself or ageing processes $[21,23]$. WHO has been guided that the ART should initiate when the CD4 count falls to 350 cells $/ \mu \mathrm{L}$ [23].

The unavailability of the CD4 count and its relatively high cost in underdevelopment countries is still challenges nowadays. Studies about benefits of TLC count as a surrogate marker of immune function and to initiate ART in HIV infected patients has been conducted elsewhere [17,24-25].

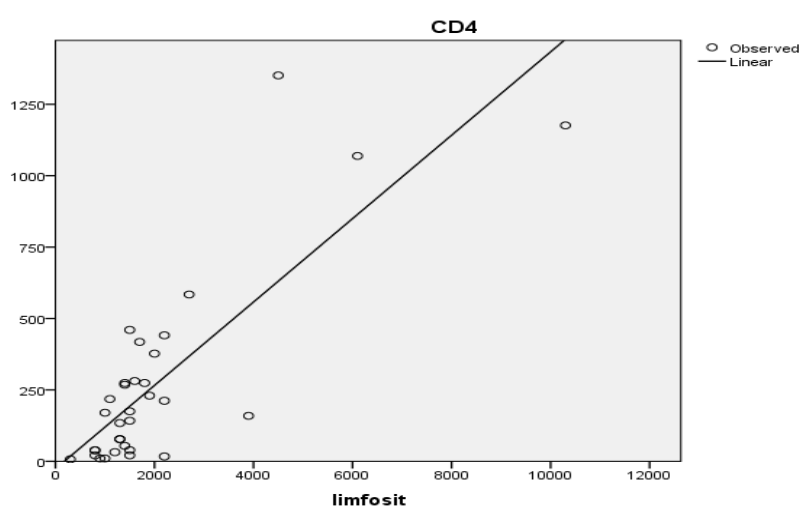

Fig. 1. Correlation between TLC and CD4 count of the participant. 
The study reported that the proportion of male cases was higher than in the case of women who were in conformity with reports from the Indonesian Ministry of Health, whereas most (almost 60\%) of HIV cases in Indonesia occurred in men [26]. Men at higher ris for HIV infection May be associated with higher mobility or higher insecure sexual activity, including male sex activity [27]. The study findings contrasted with other studies that found that women had a higher risk of acquiring HIV infection [28].

Distribution of the participant reveals the HIV infection has been spreading to all region of Gianyar regency. This may cause by the fact that Gianyar includes Ubud village is the attractive tourism destination in Bali. But the impact of tourism to a prevalence of HIV infection needs further investigation or research.

The total lymphocyte count of the participants was between $300-10300$ cells $/ \mu \mathrm{L}(2018.18 \pm 1871.91)$. This study found a positive correlation between TLC and CD4 count with Pearson correlation (which $\mathrm{r}=0,811 ; \mathrm{p}=$ 0,000 ), meanwhile other study found low sensitivity or specificity of TLC as a surrogate measure of CD4 count [25]. Similar finding found by others study where TLC serves as a surrogate marker for CD4 count in ART naïve patients [17], what was observed in India [15], Ethiopia [29] or Iran [30]. This discordance finding may be related with different study design, different design in including or excluding the participant or relatively different technique on measuring the variables. Variability of the TLC in HIV infection is depends on numerous factors such as disease severity, nutrition, diurnal cycles, stress or any sign of microbial infectio [31]. The relatively low sensitivity and specificity in the study may cause by the relatively low sample size that should be addressed in the future research. Limitations of the study are low samples size, regardless the HIV disease severity, and the presentation of opportunistic infections.

\section{Conclusion}

The positive correlation between TLC and CD4 count may use for a surrogate marker in underdevelopment countries in initiating ART or monitoring the effect of ART.

\section{References}

1. A A Okoye, L J Picker. Immunol Rev 254, 1. (2013)

2. N Merindol, L Berthoux. Curr HIV Res. 13, 6. (2015)

3. Hernandez and Sherman. Curr Opin HIV AIDS 6, 6. (2011)

4. J W Sleasman, $\mathrm{M}$ M Goodenow and $\mathrm{J}$ A C Immunol, 111, 2. (2003)

5. M S Cohen, G M Shaw, A J M Michael, B F Haynes and N Engl. J Med 364, 20. (2011)
6. World Health Organization HIV/AIDS.

7. World Health Organization. World Heal Organ 4911, 866. (2010)

8. Kementerian Kesehatan Republik Indonesia Pedoman pengobatan antiretroviral Peraturan Meteri Kesehat Republik Indones Nomor 87 Tahun 2014

9. D Asboe, C Aitken and M Boffito et al. HIV Med 13, 1. (2012)

10. N S Ku, J O Oh and S Y Shin et al. AIDS Res Hum Retroviruses 29, 2. (2012)

11. R González, R Ataíde, D Naniche, C Menéndez and A Mayor. Epidemiological Evidence 10, 2. (2012)

12. http://www.medscape.com/viewarticle/759555_2

13. J Casseb, M P Posada-Vergara and P Montanheiro et al. Rev Inst Med Trop Sao Paulo 49, 4. (2007)

14. P Sellier, C Lafuente-Lafuente, J F Bergmann and N Engl. J Med 362, 3. (2010)

15. J Andrieu, W Lu. 1. (2004)

16. S Sreenivasan, V Dasegowda. J Glob Infect Dis 3, 3. (2011)

17. World Health Organization. Scaling Up Antiretroviral Therapy in Resource Limited Settings: Guidelines for a Public Health Approach Infect Dis Clin Pract 11, 3. (2002)

18. C Obirikorang, L Quaye and I Acheampong. BMC Infect Dis 12. (2012)

19. D Daka, E Loha. AIDS Res Ther 5. (2008)

20. Y Shao, C Williamson. Cold Spring Harb Perspect Med 2, 3. (2012)

21. F J Palella, K Delaney and A Moorman. N Engl J Med p338. (1998)

22. S Masyeni, S Utama, A Somia, R Widiana and T P. Merati. Indones J Intern Med 45, 3. (2013)

23. A M Margolis, $\mathrm{H}$ Heverling, $\mathrm{P}$ A Pham and A Stolbach. J Med Toxicol 10, 1. (2014)

24. World Health Organization, When to start ART 2016 In Consolidated Guidelines on the Use of Antiretroviral Drugs for Treating and Preventing HIV Infection Recommendations for a Public Health Approach

25. G M Ashir, A I Rabasa, M M Gofama, M Gimba and L J Mshelia. Internet J Infect Dis 9, 1. (2010)

26. D Daka, E Loha. AIDS Res Ther 5. (2008)

27. Kemenkes RI. Situasi Penyakit HIV AIDS Di Indonesia. (2016)

28. B A Koblin, M J Husnik and G Colfax et al. AIDS 20, 5. (2006)

29. M K Smith. Gend Dev 10, 3. (2010)

30. F Asrie, B Gelaw, $M$ Alem, $F$ Moges and $T$ Awoke. Ethiop J Heal Dev. 27, 1. (2013)

31. C I Emuchay, S O Okeniyi and J O Okeniyi. Pakistan J Biol Sci 17, 4. (2014) 